\title{
Effects of Additive Manufacturing on the Mechanical and Corrosion Properties of Austenic Stainless Steel
}

\author{
János Endre MARÓTI, ${ }^{1}$ Dávid Miklós KEMÉNY, ${ }^{2}$ Dóra KÁROLY ${ }^{3}$ \\ Budapest University of Technology and Economics, Faculty of Mechanical Engineering, Department of \\ Materials Science and Engineering, Budapest, Hungary \\ ${ }^{1}$ maroti@eik.bme.hu \\ ${ }^{2}$ kemenydavid@edu.bme.hu \\ ${ }^{3}$ kdora@eik.bme.hu
}

\begin{abstract}
Additive manufacturing (AM) offers the possibility to produce complex parts without the design constraints of traditional manufacturing routes. Our aim was to determine different mechanical and corrosion properties of direct metal laser sintered austenitic stainless steel (X2CrNiMo17-12-2) material with tensile test, Charpy impact test, scanning electron microscopy and corrosion test. The measured values were evaluated, and our results compared with literary values, furthermore, we also examined how the printing direction affects the properties.
\end{abstract}

Keywords: additive manufacturing, austenitic stainless steel, corrosion, mechanical testing.

\section{Introduction}

Products made with additive manufacturing technology (AM) are becoming more popular and widespread, their qualities are getting better, and this meets the demands of quality in the industrial field. Furthermore, it makes possible the production of different geometries or components that would be very expensive or would not have even been possible to produce with other material manufacturing technology just a few years ago. They can now be made to high standards using a wide range of metal powders. Additive manufacturing is no longer solely a prototyping technology, but is now being used for the production of series components for the most demanding applications [1].

We can separate the production process into several phases. First, we need a 3D model that can be designed with a specific CAD (Computer Aided Design) software. This 3D model needs to be converted to STL (Standard Tessellation Language) format, which grants connections between the 3D software and the AM technology. The STL file simulates the model surface with triangles which means if the triangles are smaller than the original geometry of the model it is more accurate [1,2].
Additive manufacturing has seven major types [3] distinguished by the technology used to build the 3D body. The specimen that we used was made with Direct Metal Laser Sintering (DMLS) technology, where the energy source is the laser beam. In this technology only metal alloy powders are used.

First, the powder of the chosen material is added to the construction platform in one 50-100 $\mu \mathrm{m}$ thick layer. After this, the desired cross section is lighted and heated to near melting temperature until the particles are chemically fused by laser. After the layer is created, the construction platform moves down then the printer adds another layer $[1,2]$. The finished product is removed from the powder and is usable after cleaning.

The most important advantage of DMLS is that high geometric accuracy and good surface quality can be achieved without support and surface-treatment. Due to the pre-heating, the product will also have less residual stress. The technology can also be applied to high-strength materials $[4,5]$.

Previous research has shown that production parameters like laser scanning speed, distance between laser path, linear-, surface- and volu- 
metric energy density modification and their relationship to each other [6], as well as porosity of the specimen [7] are most affecting the microstructure and mechanical properties (Young's modulus, Yield strength) of 3D printed specimens.

An interesting question is to examine the 3D printability of various complex geometric medical implants (e.g. coronary artery stents, orthopaedic implants with bone like structure). Thus, the purpose of our research is also to study a commonly used biocompatible material: austenitic stainless steel (316L steel).

\section{Materials and methods}

Our specimens were X2CrNiMo17-12-2 steel manufactured with an EOS M100 direct metal laser sintering 3D printer (specimen marked with: A) or traditionally manufactured (specimen marked with: $\mathrm{H})$.

\subsection{Charpy impact test}

Six samples were used for the Charpy impact test with edge lengths of $l_{1}=55 \mathrm{~mm}$ and $l_{2}=10 \mathrm{~mm}$, thickness of $\mathrm{h}=2.5 \mathrm{~mm}$, and V-notch of $2 \mathrm{~mm}$ deep, with $45^{\circ}$ angle. Half of these were additive manufactured, the others were traditionally manufactured from a bulk material.

We also used three standardised specimens with edge lengths of $l_{1}=55 \mathrm{~mm}$ and $l_{2}=10 \mathrm{~mm}$, thickness of $\mathrm{h}=10 \mathrm{~mm}$, and V-notch of $2 \mathrm{~mm}$ deep, with $45^{\circ}$ angle. The sample were tested at room temperature by WPN Charpy impact testing device according to [8].

\subsection{Tensile test}

For the tensile test we used 16 pieces of additive manufactured A marked specimens in total. 10 pieces were with a total length of $L_{t}=70 \mathrm{~mm}$, original gauge length of $\mathrm{L}_{0}=27.5 \mathrm{~mm}$, thickness of $\mathrm{a}_{0}=2 \mathrm{~mm}$, width of $\mathrm{b}_{0}=2,5 \mathrm{~mm}$ and testing length of $\mathrm{L}_{\mathrm{c}}=40 \mathrm{~mm}$ (hereafter referred to as the long specimen). The other samples for tensile test were a total length of $L_{t}=37 \mathrm{~mm}$, thickness of $\mathrm{a}_{0}=2 \mathrm{~mm}$ and width of $\mathrm{b}_{0}=6 \mathrm{~mm}$, without original gauge length (hereafter referred to as the short specimen).

In addition, the direction of construction of the specimen layers was also varied. Some were printed vertically (the support being placed on the smaller side of the workpiece) and some horizontally (the support material was positioned on the larger side of the workpiece). Half of the long specimens were horizontally, half vertically pro- duced. One of the short specimens was printed horizontally, the others were vertically produced. Our results were compared with the manufacturer's data, according to the horizontal test specimens data: $\mathrm{R}_{\mathrm{m}}=650 \mathrm{MPa}, \mathrm{R}_{\mathrm{p} 0,2}=535 \mathrm{MPa}, \mathrm{A}=35 \%$ and the horizontal test specimens data: $\mathrm{R}_{\mathrm{m}}=590$ $\mathrm{MPa}, \mathrm{R}_{\mathrm{p} 0,2}=490 \mathrm{MPa}, \mathrm{A}=45 \%$ [9].

The samples were tested with an MTS 810 universal hydraulic mechanical tester, under a constant loading speed of $3 \mathrm{~mm} / \mathrm{min}$ at room temperature based on MSZ EN ISO 6892-1 standard [10].

\subsection{Corrosion test}

For the corrosion test cylindrical samples were 3D printed, with a diameter of $\mathrm{d}=15 \mathrm{~mm}$, and a height of $h=6 \mathrm{~mm}$ were used. We needed a corrosion cell to do the corrosion test (Figure 1.). The corrosion cell includes: a supersaturated $\mathrm{KCl}$ solution calomel electrode, which is the reference electrode; a Pt electrode, which is the counter electrode, a potentiostat with a computer, 250 millilitre glass measuring cup, a digital heating plate and a stand.

For the tests, $0.9 \%$ and $3.5 \% \mathrm{NaCl}$ solution was used for the corrosion medium, which simulated the prevailing environment in the body and the seawater. During the measurement with the physiological saline solution, the solution was heated to $37 \pm 2{ }^{\circ} \mathrm{C}$, thus approaching the conditions in the body.

At time 0 , the current density voltage diagram also called the Tafel curve was measured, and this was repeated 1, 2, 3, 4, and 5 hours later. The tests were performed and evaluated according to ASTM G 102 [11]

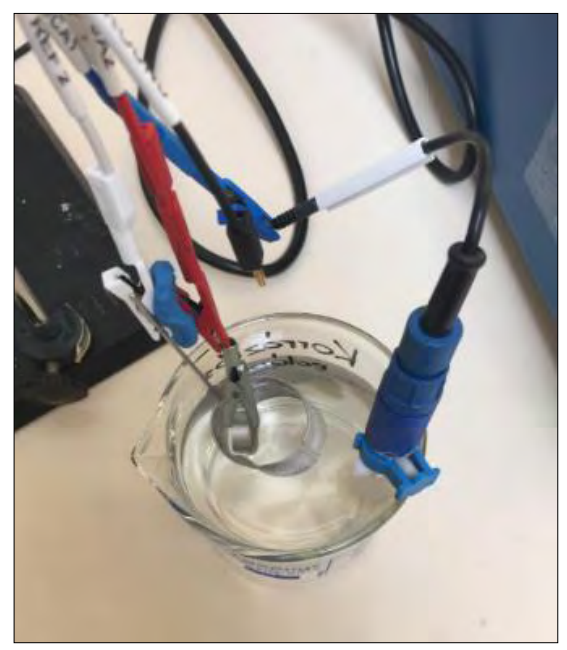

Figure 1. Corrosion measuring arrangement 
Similar measurements were made by L. Absora and his coworkers who measured the corrosion of the X2CrNiMo17-12-2 steel we tested in a $3 \% \mathrm{NaCl}$ solution, with a corrosion rate of $0.0071 \mathrm{~mm} /$ year [12].

The composition of the samples material were determined by Zeiss EVO M10 scanning electron microscopy (SEM) and the associated Octane elect EDAX (energy dispersive spectroscopy). Pictures were taken from the specimen's surface with accelerating voltage of $20 \mathrm{kV}$ before and after the corrosion tests

\section{Results}

\subsection{Charpy impact test}

The linear expansion ( $\left.e=x-x_{0}, \mathrm{~mm}\right)$, impact energy (KV, J) and the specific impact energy (KCV, $\mathrm{J} / \mathrm{mm} 2$ ) of the thin specimens were determined. The results are summarized in Table 1.

The linear expansion, impact energy and specific impact energy for the standardized samples (H10) were also determined. The results can be seen in Table 2.

The fracture surfaces were investigated by scanning electron microscopy (Figure 2.). The fractured, bland-like nature of the surfaces does not differ greatly in the case of the additively manufactured and the conventional specimens, but the presence of potholes due to porosity can be observed in the additively produced samples.

Table 1. Results of Charpy-impact test for A-marked and H-marked thin specimens

\begin{tabular}{|c|c|c|c|c|}
\hline \multicolumn{2}{|c|}{ Specimen } & \multirow{2}{*}{$\underset{(\mathrm{mm})}{\mathrm{e}}$} & \multirow{2}{*}{$\begin{array}{l}\text { KV } \\
\text { (J) }\end{array}$} & \multirow{2}{*}{$\underset{\left(\mathrm{J} / \mathbf{m m}^{2}\right)}{\mathrm{KCV}}$} \\
\hline Type & No. & & & \\
\hline $\mathrm{A} 2,5$ & 1 & 0.641 & 18 & 0.96 \\
\hline $\mathrm{A} 2,5$ & 2 & 0.917 & 18 & 0.96 \\
\hline $\mathrm{A} 2,5$ & 3 & 0.625 & 18 & 0.96 \\
\hline $\mathrm{H} 2,5$ & 1 & 1.07 & 27 & 1.44 \\
\hline $\mathrm{H} 2,5$ & 2 & 1.07 & 28 & 1.49 \\
\hline $\mathrm{H} 2,5$ & 3 & 1.09 & 29 & 1.55 \\
\hline
\end{tabular}

Table 2. Enlargement (e) and absorbed energies ( $K V$ and $K C V$ ) of specimen serie $H$

\begin{tabular}{|c|c|c|c|c|}
\hline \multicolumn{2}{|c|}{ Specimen } & \multirow{2}{*}{$\begin{array}{c}\mathrm{e} \\
(\mathbf{m m})\end{array}$} & \multirow{2}{*}{$\begin{array}{l}\text { KV } \\
\text { (J) }\end{array}$} & \multirow{2}{*}{$\underset{\left(\mathrm{J} / \mathbf{m m}^{2}\right)}{\mathbf{K C V}}$} \\
\hline Type & No. & & & \\
\hline H10 & 1 & 1.4 & 99 & 1.32 \\
\hline H10 & 2 & 1.2 & 118 & 1.57 \\
\hline $\mathrm{H} 10$ & 3 & 1.1 & 134 & 1.65 \\
\hline
\end{tabular}

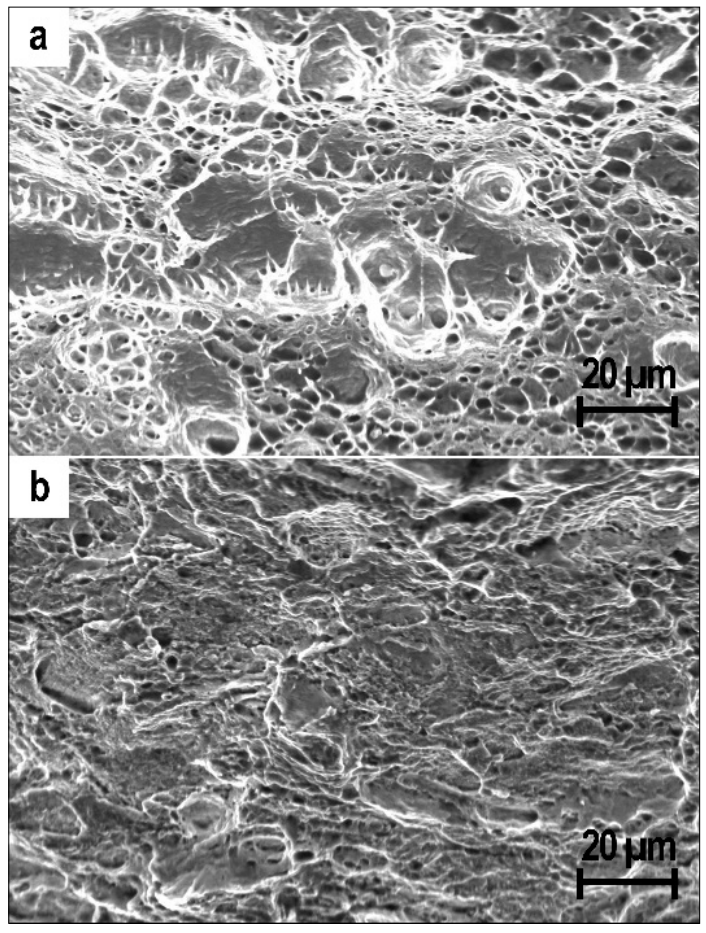

Figure 2. Scanning electron microscopic image of fracture surfaces after Charpy impact test, additively manufactured (a), conventionally manufactured specimen (b)

\subsection{Tensile test}

The tensile ( $F-\Delta L$, force-displacement) diagram of one horizonal and one vertical long specimen can be seen in Figure 3. We did not represent the tensile diagram of all the test specimens, because the difference between the two layers of the construction direction is thus more visible.

The average Yield strength $\left(R_{p 0,2}\right)$, elastic modulus $(E)$, tensile strength $\left(R_{m}\right)$, elongation at break $(A)$ and contraction $(Z)$ of the long specimens are shown in Table 3. together with the standard deviation.

The measurement was repeated for the short specimens. For a better illustration of these specimens, the tensile curves of a vertically and horizontally produced workpiece are shown in Figure 4.

Table 3. Specification of long specimens

\begin{tabular}{|c|c|c|c|c|c|}
\hline $\begin{array}{c}\text { Print } \\
\text { direc. }\end{array}$ & $\begin{array}{c}\mathbf{R}_{\mathrm{p} 02} \\
(\mathbf{M P a})\end{array}$ & $\begin{array}{c}\mathbf{E} \\
\mathbf{G P a})\end{array}$ & $\begin{array}{c}\mathbf{R m} \\
\mathbf{( M P a})\end{array}$ & $\begin{array}{c}\mathbf{A} \\
\mathbf{( \% )}\end{array}$ & $\begin{array}{c}\mathbf{Z} \\
\mathbf{( \% )}\end{array}$ \\
\hline Hor. & $520 \pm 43$ & $138 \pm 16$ & $604 \pm 20$ & $23.83 \pm 2.25$ & $41.8 \pm 7.54$ \\
\hline Vert. & $460 \pm 17$ & $111 \pm 12$ & $558 \pm 18$ & $26.5 \pm 1.9$ & $54 \pm 5.2$ \\
\hline
\end{tabular}


The average and standard deviation of Yield strength, tensile strength and contraction of short specimens are shown in Table 4.

\subsection{Corrosion test}

Figure 5. shows that during the physiological saline corrosion test at near body temperature (which simulates conditions in the body), the spheres on the surface of the additively produced sample (which are metal splashes due to the laser melting) are released in several places.

The measurements of Tafel curves (corrosion-current density versus potential diagram) obtained in physiological saline are shown in Figure 6. From the curves we get the corrosion rate characteristic of the work piece. During the evaluation, the tangents are aligned with the linear

Table 4. Specification of short specimens

\begin{tabular}{|c|c|c|c|}
\hline $\begin{array}{c}\text { Print } \\
\text { direction }\end{array}$ & $\begin{array}{c}\mathbf{R}_{\mathbf{p} 2} \\
(\mathbf{M P a})\end{array}$ & $\begin{array}{c}\mathbf{R}_{\mathbf{m}} \\
(\mathbf{M P a})\end{array}$ & $\begin{array}{c}\mathbf{Z} \\
\mathbf{( \% )}\end{array}$ \\
\hline Hor. & 565 & 735 & 26.2 \\
\hline Vert. & $600 \pm 20$ & $656 \pm 19$ & $39.9 \pm 2.3$ \\
\hline
\end{tabular}

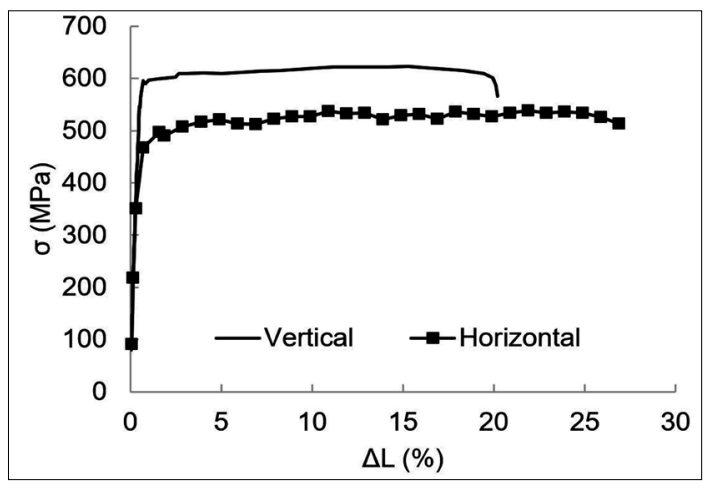

Figure 3. Tensile test diagram of long specimens

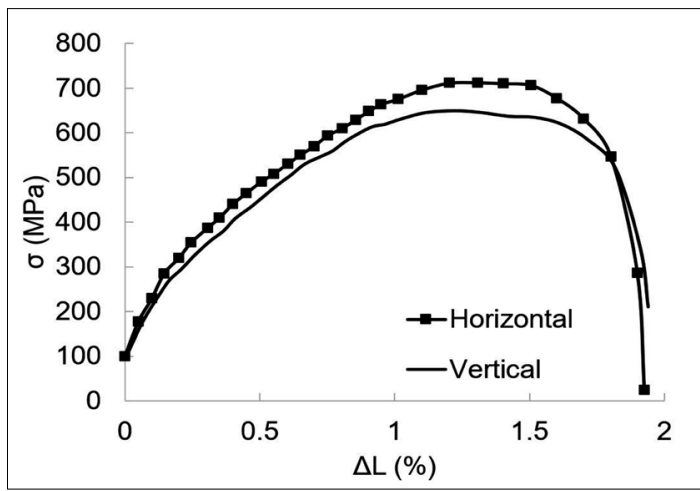

Figure 4. Tensile test diagram of short specimens section of the Tafel curve, taking into account the equilibrium corrosion potential $\left(E_{\text {corr }}\right)$. The point of intersection of the tangents gives the current that is entered into the required formulas [11] to obtain the corrosion rate.

The surface of the specimens that were in contact with the corrosion medium was determined from the stereomicroscope images. In the case of the specimen used in the physiological saline solution, this is $\mathrm{A}=0.88 \mathrm{~cm}^{2}$, while in the case of seawater saline, the specimen surface area that contacted the corrosion medium is $\mathrm{A}=0.875 \mathrm{~cm}^{2}$. The weight $\%$ and atomic $\%$ were measured by

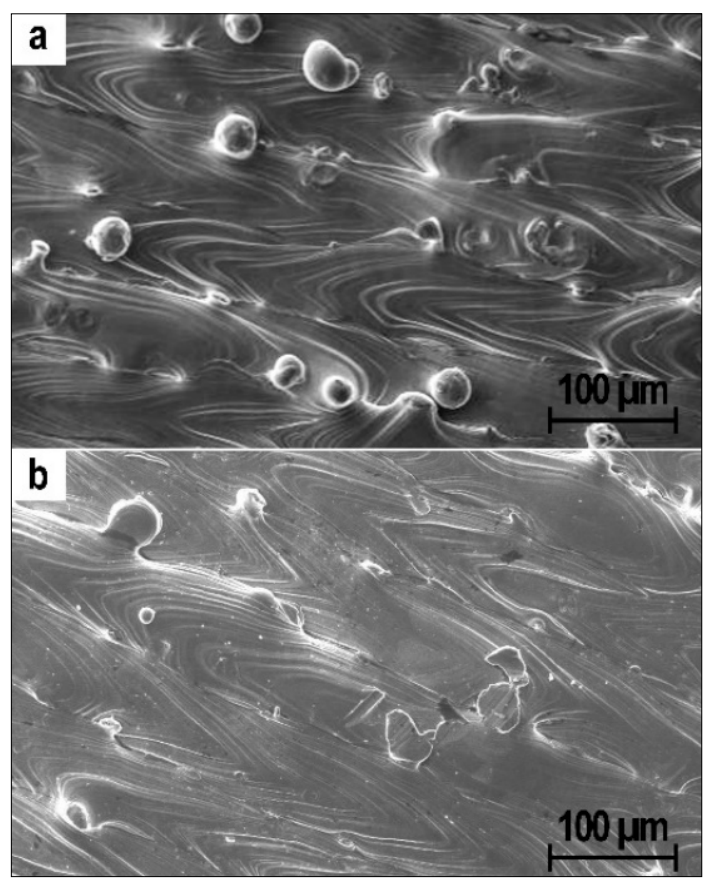

Figure 5. Surface of additively manufactured specimens before (a) and after (b) corrosion test

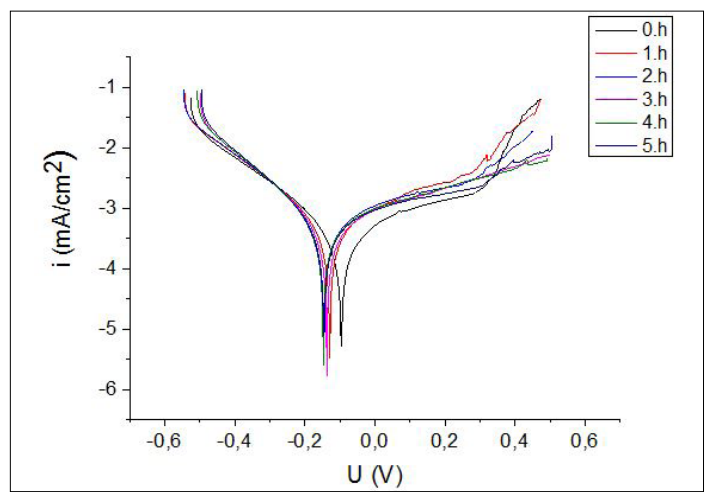

Figure 6. Tafel curves of additively manufactured samples, $0.9 \% \mathrm{NaCl}$ at $0-5$. hours 
SEM-EDS analysis. The material composition of the specimens is summarized in the following table (Table 6.).

Based on these data, the density was $\rho=7.814 \mathrm{~g} / \mathrm{cm}^{3}$, and the equilibrium mass was $E_{w}=17.164$. Corrosion rates $\left(v_{\text {corr }}\right)$ are listed in Table 7 .

Figure 7. shows the temporal changes in corrosion rates. It can be seen that the corrosion rate values measured in saline solution are smaller at 1,2 , and 3 hours than in seawater, and the corrosion rates measured in $0.9 \%$ saline are exaggerated, due to high porosity and corrosion caused surface errors. However, a corrosion rate maximum of $0.13 \mathrm{~mm} /$ year is generally acceptable for biocompatible materials. All of our values are lower, so the additively manufactured material is adequate for medical use.

Table 6. Material composition of additively manufactured specimens

\begin{tabular}{|c|c|}
\hline Element & Weight \% \\
\hline $\mathrm{Fe}$ & $62.33-63.91$ \\
\hline $\mathrm{Cr}$ & $20.38-22.15$ \\
\hline $\mathrm{Ni}$ & $10.49-12.81$ \\
\hline $\mathrm{Mo}$ & $1.66-2.74$ \\
\hline $\mathrm{Mn}$ & $1.09-2.37$ \\
\hline $\mathrm{Si}$ & $0.13-0.55$ \\
\hline
\end{tabular}

Table 7. AM specimens' corrosion rates

\begin{tabular}{|c|c|c|}
\hline \multirow{2}{*}{$\mathbf{t}(\mathbf{h})$} & \multicolumn{2}{|c|}{$\mathbf{v}_{\text {korr }}(\mathbf{m m} / \mathbf{y r})$} \\
\cline { 2 - 3 } & $\mathbf{0 , 9} \% \mathbf{~ N a C l}$ & $\mathbf{3 , 5} \% \mathbf{~ N a C l}$ \\
\hline 0 & 0.00023 & 0.0035 \\
\hline 1 & 0.00096 & 0.0056 \\
\hline 2 & 0.00133 & 0.0061 \\
\hline 3 & 0.00100 & 0.0050 \\
\hline 4 & 0.01668 & 0.0059 \\
\hline 5 & 0.01541 & 0.0057 \\
\hline
\end{tabular}

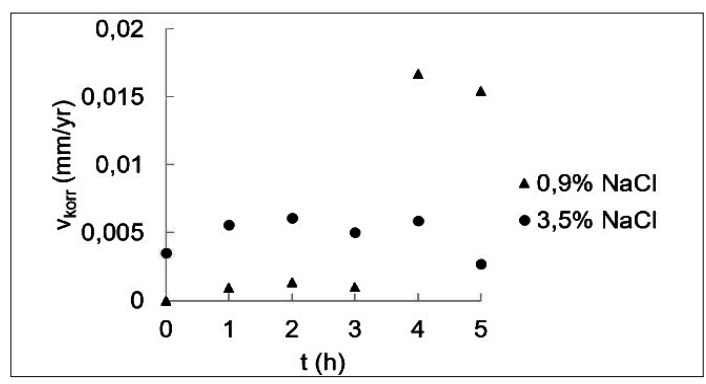

Figure 7. Corrosion rate of AM specimens as a function of time

\section{Conclusions}

\subsection{Charpy impact test}

To compare the specimens, which were produced by two different manufacturing processes the specific impact energy was ideal from the other result values of the impact test.

For the H2.5-marked specimens, the average specific impact energy was $\mathrm{KCV}=1.493 \mathrm{~J} / \mathrm{mm}^{2}$, for the H10-marked specimens the average specific impact energy was $\mathrm{KCV}=1.513 \mathrm{~J} / \mathrm{mm}^{2}$, in contrast the average specific impact energy for the A2.5 marked specimens was $\mathrm{KCV}=0.96 \mathrm{~J} / \mathrm{mm}^{2}$. It can be seen that there is no significant difference between the same manufactured specimens, so the size reduction had no effect on these properties.

However, the difference between A-marked and H-marked specimens' specific impact energy is $0.543 \mathrm{~J} / \mathrm{mm}^{2}$, which was due to the porosity in the additively manufactured specimens.

All of the specimens were shown though their behaviour at room temperature.

\subsection{Tensile test}

Based on the tensile test it can be concluded that the short specimens are not suitable for determination of the mechanical properties, because with their geometry it is not possible to perform the test (insertion of extensometer was not possible), furthermore the notch in the center of the specimens is a stress concentrator.

The results of the long specimens indicate the tendency that the mechanical properties of the horizontally printed specimens are better than the vertically printed specimens. In the case of long test specimens, a difference is $60 \mathrm{MPa}$ in yield strength, $27 \mathrm{GPa}$ in elastic modulus and $46 \mathrm{MPa}$ in tensile strength. In both cases this is in favour of the horizontally printed specimens. Comparing the measured results with the manufacturer's data [9] we can see that the Yield strength, tensile strength and elongation at break are higher in the manufacturer's data sheet than the value we have measured. This may be due to improper print settings that cause greater porosity in the material.

\subsection{Corrosion test}

The obtained corrosion rates were compared with the values found in the literature. The values obtained in physiological $0.9 \%$ saline did not exceed the biocompatibility limit. The literature values were $0.0071 \mathrm{~mm} / \mathrm{yr}$ [12], however we got $0.0053 \mathrm{~mm} / \mathrm{yr}$. This difference $(0.0018 \mathrm{~mm} / \mathrm{yr})$ can be due to the characteristics of additive manufac- 
turing technology, the surface roughness and the degree of porosity.

\section{Acknowledgement}

The project is funded by the National Research, Development and Innovation (NKFIH) Fund. Project title "Developing a new generation of customized medical aids for additive technologies". The application ID number: NVKP-16-1-2016-022. The developers are grateful for the support.

The publication of the work reported herein has been supported by ETDB at BME. The authors gratefully acknowledgments the sponsorship.

\section{References}

[1] Redwood B., Schöffer F. , Garret B.: The 3D Printing Handbook: Technologies, design and applications. 1. kiadás. Coers \& Roest, Amsterdam, 2017. 123-137.

https://doi.org/10.1007/978-981-13-8281-9

[2] Keresztes Z., Pammer D., Károly D., Szabó J. P.: EBSD examination of Ti-6Al-4V samples prodiced with additive technology. IOP Conference Series: Materials Science and Engineering 426012025 (2018) https://doi.org/10.1088/1757-899X/426/1/012025

[3] MSZ EN ISO/ASTM 52900:2017 Additív gyártás. Általános alapelvek. Terminológia (ISO/ASTM DIS 52900:2017)

[4] Zhang X.-Y., Fang G., Zhou J.: Additively Manufactured Scaffolds for Bone Tissue Engineering and the Prediction of their Mechanical Behavior: A Review. Material, 10/1. (2017) 50. https://doi.org/10.3390/ma10010050
[5] Gu D., Shen Y.: Processing conditions and microstructural features of porous $316 L$ stainless steel components by DMLS. Applied Surface Science, 255 (5)/1. (2008) 1880-1887. https://doi.org/10.1016/j.apsusc.2008.06.118

[6] Chen S. Y., et al.: Microsstructure and mechanical properties of open-cell porous TI-6AL-4V fabricated by selective laser melting. Journal of Alloys and Compounds, 713. (2017) 248-254. https://doi.org/10.1016/j.jallcom.2017.04.190

[7] Mahmoudi M., et al.: On the printability and transformation behavior of nickel-titanium shape memory alloy fabricated using laser power-bed fusion additive manufacturing. Journal of Manufacturing Processes, 35. (2018) 672-680. https://doi.org/10.1016/j.jmapro.2018.08.037

[8] MSZ EN ISO 148-1:2017 Fémek. Charpy-féle ütővizsgálat. 1. rész: Vizsgálati módszer (ISO 148-1:2016)

[9] EOS Anyag adatlap, 316L. (2019. 02.2 0.) www.eos.info/material-m

[10] MSZ EN ISO 6892-1:2016 Fémek. Szakítóvizsgálat. 1. rész: Vizsgálat szobahőmérsékleten (ISO 6892-1:2016)

[11] ASTM G102 - 89(2015): Standard Practice for Calculation of Corrosion Rates and Related Information from Electrochemical Measurements.

[12] Absora L., Ashour A. F., Mitchell S. C., Youseffi M.: Corrosion of mild steel and $316 \mathrm{~L}$ austenitic stainless steel with different surface roughness in sodium chloride saline solutions. WIT Transactions on Engineering Sciences, Vol 65, ISSN 1743-3533. (2009) 168. https://doi.org/10.2495/ECOR090161 